\title{
Studies on Hypoglycaemia in Small-for-dates Newborns
}

\author{
D. BLUM, J. DODION, H. LOEB,$\uparrow$ P. WILKIN,$\ddagger$ and P. O. HUBINONT \\ From the Departments of Paediatrics and Gynaecology and Obstetrics, Faculty of Medicine, \\ University of Brussels, Belgium
}

In the past few years, new knowledge has accumulated on the subject of transient neonatal hypoglycaemia. This problem has been fully reviewed by Cornblath and Schwartz (1966a, b) who attempt to clarify the incidence, clinical features, treatment, outcome, and pathogenesis of this syndrome. Their data indicate that hypoglycaemia occurs predominantly in infants whose birthweights are low for gestational age (Gruenwald, 1965a) ('smallfor-dates'). In a significant number of cases there is, in addition, a history of pre-eclampsia or toxaemia of pregnancy. The association of toxaemia gravidis and neonatal hypoglycaemia might suggest a direct link between the two conditions (Cornblath, Odell, and Levin, 1959), but intrauterine malnutrition, rather than toxaemia gravidis by itself, is now known to predispose to hypoglycaemia in the newborn (Shelley and Neligan, 1966).

The real physiopathological mechanisms, however, have not been elucidated. By comparison with what has been observed in babies of diabetic mothers, hyperinsulinism has been suggested as a cause of hypoglycaemia, but this hypothesis is no longer tenable (Cornblath and Schwartz, 1966a).

The low level of hepatic glycogen found at necropsy by Shelley (1964) and Dawkins (1964) has led some observers (Brown and Wallis, 1963; Chance and Bower, 1966; Cornblath and Schwartz, 1966b; Shelley and Neligan, 1966) to incriminate exhaustion as a possible mechanism for hypoglycaemia. The high ratio of brain weight to liver weight (Cornblath and Schwartz, 1966b; Dawkins, 1964; Gruenwald, 1965b; 1966b; Shelley and Neligan, 1966), and the state of hypermetabolism (Silverman and Sinclair, 1966) found in these babies support the hypothesis advocated by Cornblath and

Received September 26, 1968.

^Present address: Hôpital St-Pierre, Bruxelles, Belgique.

†Supported by the Foundation "Princesse Marie-Christine".

$\ddagger$ Supported by Grant number 5 R 01 HD 02365-02 Department of Health, Education and Welfare.
Schwartz (1966b) that relatively diminished liver glycogen in the presence of enhanced metabolic requirements might be an important factor in the hypoglycaemia of such infants.

None of these hypotheses is wholly satisfactory. For that reason, a study comparing 'small-fordates' babies with normal infants is presented here.

\section{Material and Methods}

Two groups of children were studied ${ }^{\star}$ (Fig. 1 and 2).

Group I. 34 infants ( 28 term and 6 pre-term infants) whose weights were both less than mean weight minus 2SD according to Hendricks's (1964) chart and below the 5th centile (Gruenwald, 1966a).

Group II. 31 term controls ( $>37$ weeks' gestation) whose birthweights were more than the mean weight minus 1 SD on Hendricks's chart.

No congenital abnormalities were noted in either group nor was any death recorded during the neonatal period. Delivery and the course after delivery were normal in all control subjects.

Table I includes information ab sut weight, length, head circumference, pregnancy, delivery, and perinatal events for the group of small-for-dates infants.

The aim was to collect three blood samples from each infant but in few cases were all these samples taken. The first sample was taken within 24 hours of birth before the child had been fed, the second and third samples 6 hours after feeding between the first and third day, and between the third and fifth day.

Blood glucose was measured before, and 10, 20, and 30 minutes after intravenous injection of glucagon (300 $\mu \mathrm{g} . / \mathrm{kg}$.). Blood samples obtained by heel-prick were carried out on $0.1 \mathrm{ml}$. of blood, according to the glucose oxidase method (Biochemica test, Boehringer). Other blood samples were obtained by venous femoral puncture for determination of free fatty acids (FFA), lactic acid, and pyruvic acid. After immediate centri-

* The parents were duly informed and permission was asked and given for the studies related in this paper.

Glucagon was kindly supplied by Dr. J. Hubert, Novo Industri, Scientific Department of Belgium. 


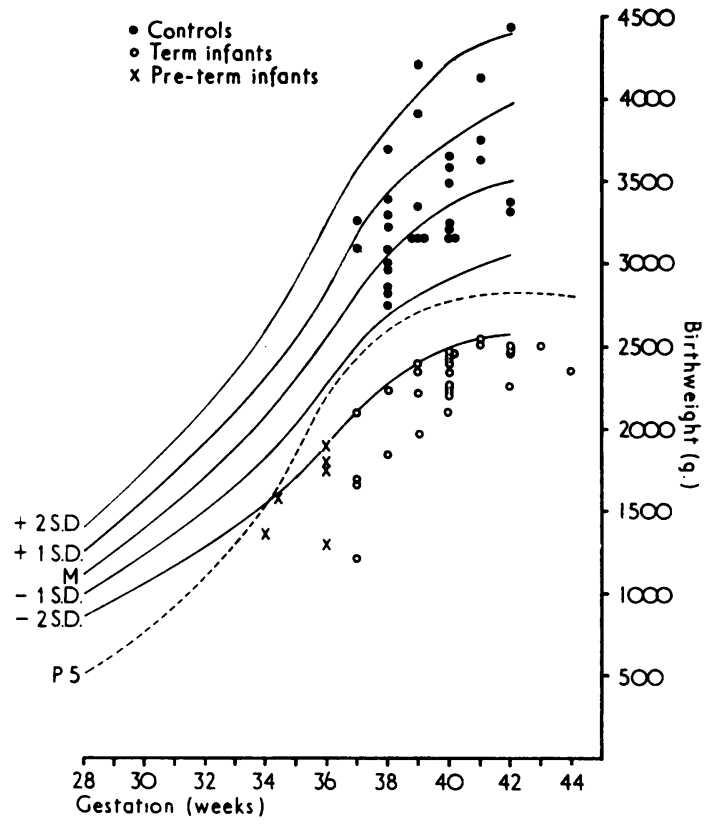

FIG. 1.-Birthweight in relation to gestational age. Values are plotted on Hendricks's chart (mean and SD, solid lines) and on Gruenwald's curve (5th centile, dotted line).

fugation, FFA were determined according to Dole (1956). After immediate deproteinization, enzymatic procedures were used for the determination of lactic

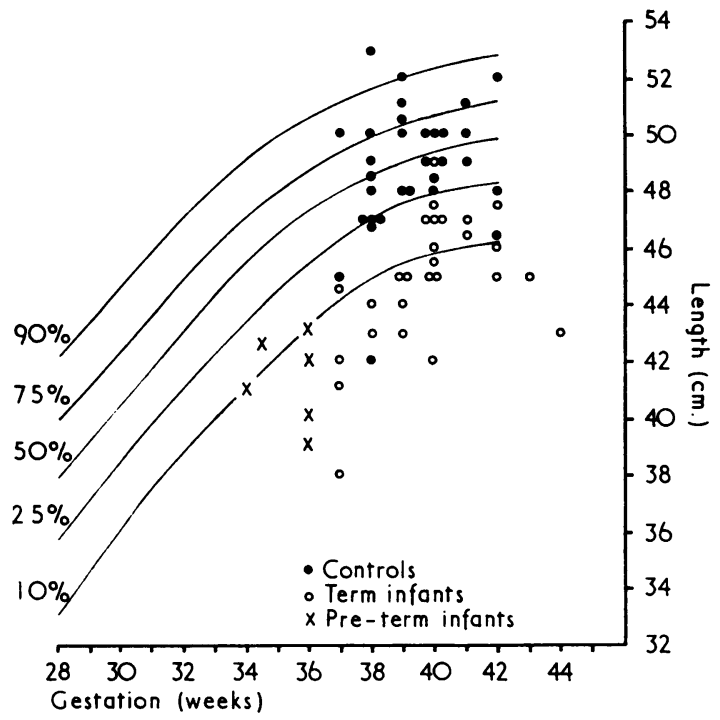

FIG. 2.-Birth length in relation to gestational age. Values are plotted on Lubchenco's chart (centiles) (Lubchenco, Hansman, and Boyd, 1966). and pyruvic acids (Lundholm, Mohme-Lundholm, and Svedmyr, 1963; Gloster and Harris, 1962).

\section{Results}

The results are summarized in Tables II and III. The fasting mean blood sugar of babies with low birthweight for gestational age lay between 39 and $47 \mathrm{mg}$. $/ 100 \mathrm{ml}$., the control levels varying from 50 to $60 \mathrm{mg}$. $/ 100 \mathrm{ml}$.

Fig. 3 shows that the individual values in both groups are very scattered, hence a large standard deviation with much overlapping of results. There are no significant differences between the values of the two groups.

All controls had a fasting glucose level above $30 \mathrm{mg} . / 100 \mathrm{ml}$. On the other hand, 13 samples obtained from 10 of the 28 children in group I were under $30 \mathrm{mg} . / 100 \mathrm{ml}$., of which 6 samples obtained from 5 infants were below $20 \mathrm{mg} . / 100 \mathrm{ml}$.

Intravenous glucagon in doses of $300 \mu \mathrm{g} . / \mathrm{kg}$. resulted, in both groups, in a prompt and similar increase in the level of glycaemia (Fig. 3). No correlation was found between the glucagoninduced hyperglycaemia, and the fasting blood glucose level ( $r=0 \cdot 16$ for the controls; $r=0.14$ for the small-for-dates).

In both groups, lactate/pyruvate ratio varied between 17 and 20, and the mean blood FFA level varied between 1200 and $1700 \mu \mathrm{Eq} / \mathrm{l}$. These values did not differ significantly (Fig. 3).

\section{Discussion}

A growth curve has not yet been devised for the heterogeneous population of Belgian and Mediterranean infants from which our material for study was derived. Since it was impossible to evaluate the importance of racial and socioeconomic factors (Gruenwald, 1966a, b), we had to choose between Hendricks's curves and those of Gruenwald. The simultaneous use of both graphs led us to select the children whose birthweights were both less than the mean minus 2 SD according to Hendricks's charts, and below the 5th centile according to Gruenwald's.

Our group was not homogeneous, in the sense that growth retardation sometimes involves weight alone, and sometimes weight and length. We can, however, accept Gruenwald's hypothesis that long and emaciated infants have suffered subacute intrauterine malnutrition, whereas in thin and short subjects the role of a genetic factor or of an abnormal condition like chronic intrauterine deprivation must be taken into consideration (Gruenwald, 1965b). In any case, it is now established that both of these are high risk groups (Battaglia and 
TABLE I

Small-for-dates Infants: Clinical Data

\begin{tabular}{|c|c|c|c|c|c|c|}
\hline $\begin{array}{c}\text { Patient } \\
\text { No. }\end{array}$ & Sex & $\begin{array}{c}\text { Gestational } \\
\text { Age (wk.) }\end{array}$ & $\begin{array}{c}\text { Birthweight } \\
\text { (g.) }\end{array}$ & $\begin{array}{l}\text { Birth Length } \\
\text { (cm.) }\end{array}$ & $\begin{array}{l}\text { Head } \\
\text { Circumference } \\
\text { (cm.) }\end{array}$ & Obstetric and Perinatal Events \\
\hline $\begin{array}{l}1 \\
2\end{array}$ & $\begin{array}{l}\mathbf{F} \\
\mathbf{F}\end{array}$ & $\begin{array}{l}37 \\
37\end{array}$ & $\begin{array}{l}1230 \\
1660\end{array}$ & $\begin{array}{l}38 \\
44 \cdot 5\end{array}$ & $\begin{array}{l}28 \cdot 5 \\
29 \cdot 5\end{array}$ & $\begin{array}{l}\text { No increase of uterine height; pre-eclampsia } \\
\text { Previous placental insufficiency, previous albuminuria, } \\
\text { hypertension-no increase of uterine height; caesarean } \\
\text { section for fall in oestriol }\end{array}$ \\
\hline 3 & $\mathbf{M}$ & 37 & 1680 & 41 & $29 \cdot 5$ & - \\
\hline 4 & $\mathbf{F}$ & 37 & 2110 & 42 & 30 & No increase of uterine height; muscular twitchings \\
\hline 5 & $\mathbf{F}$ & 38 & 1850 & 43 & 32 & - \\
\hline 6 & $\mathbf{F}$ & 38 & 2220 & 44 & 32 & Oedema of inferior limbs \\
\hline 7 & $\mathbf{F}$ & 39 & 1950 & 43 & 32 & Excessive maternal weight gain \\
\hline 8 & $\mathbf{M}$ & 39 & 2200 & 45 & $32 \cdot 5$ & $\begin{array}{l}\text { No increase of uterine height; pre-eclampsia cyanosis, } \\
\text { hypotonia }\end{array}$ \\
\hline 9 & $\mathbf{F}$ & 39 & 2350 & 45 & $31 \cdot 5$ & Oedema of inferior limbs \\
\hline 10 & $\mathbf{F}$ & 39 & 2400 & 44 & 31 & Pre-eclampsia \\
\hline 11 & $\mathbf{F}$ & 40 & 2130 & 46 & 32 & Normal pregnancy and neonatal period \\
\hline 12 & $\mathbf{F}$ & 40 & 2180 & 42 & 32 & $\begin{array}{l}\text { Excessive weight gain, fetal distress; persistent muscular } \\
\text { twitchings, cyanosis }\end{array}$ \\
\hline 13 & $\mathbf{F}$ & 40 & 2200 & $45 \cdot 5$ & 32 & Normal \\
\hline 14 & $\mathbf{M}$ & 40 & 2210 & 45 & 34 & Excessive weight gain, acute fetal distress \\
\hline 15 & $\mathbf{F}$ & 40 & 2240 & 45 & 32 & Excessive weight gain, no increase of uterine height \\
\hline 16 & $\mathbf{F}$ & 40 & 2350 & 49 & 33 & Acute fetal distress; cyanosis \\
\hline 17 & $\mathbf{F}$ & 40 & 2400 & $47 \cdot 5$ & 33 & No increase of uterine height; pre-eclampsia \\
\hline 18 & $\mathbf{F}$ & 40 & 2420 & 47 & $32 \cdot 5$ & $\begin{array}{l}\text { Previous placental insufficiency; no increase of uterıne } \\
\text { height }\end{array}$ \\
\hline 19 & $\mathbf{M}$ & 40 & 2440 & 47 & 33 & No increase of uterine height \\
\hline 20 & $\mathbf{F}$ & 40 & 2450 & 46 & 32 & Excessive maternal weight gain \\
\hline 21 & $\mathbf{M}$ & 40 & 2470 & 47 & 31 & Exce sive maternal weight gain \\
\hline 22 & $\mathbf{F}$ & 41 & 2500 & $46 \cdot 5$ & 34 & Normal \\
\hline 23 & $\mathbf{M}$ & 41 & 2560 & 47 & 31 & Normal \\
\hline 24 & $\mathbf{F}$ & 42 & 2250 & 45 & 34 & Normal \\
\hline 25 & $\mathbf{M}$ & 42 & 2430 & 46 & - & Normal \\
\hline 26 & $\mathbf{F}$ & 42 & 2500 & $47 \cdot 5$ & 31 & $\begin{array}{l}\text { Previous placental insufficiency; excessive weight gain; } \\
\text { cyanosis }\end{array}$ \\
\hline 27 & $\mathbf{M}$ & 43 & 2500 & 45 & $31 \cdot 5$ & - \\
\hline 28 & $\mathbf{M}$ & 44 & 2350 & 43 & 31 & Maternal hypertension \\
\hline
\end{tabular}
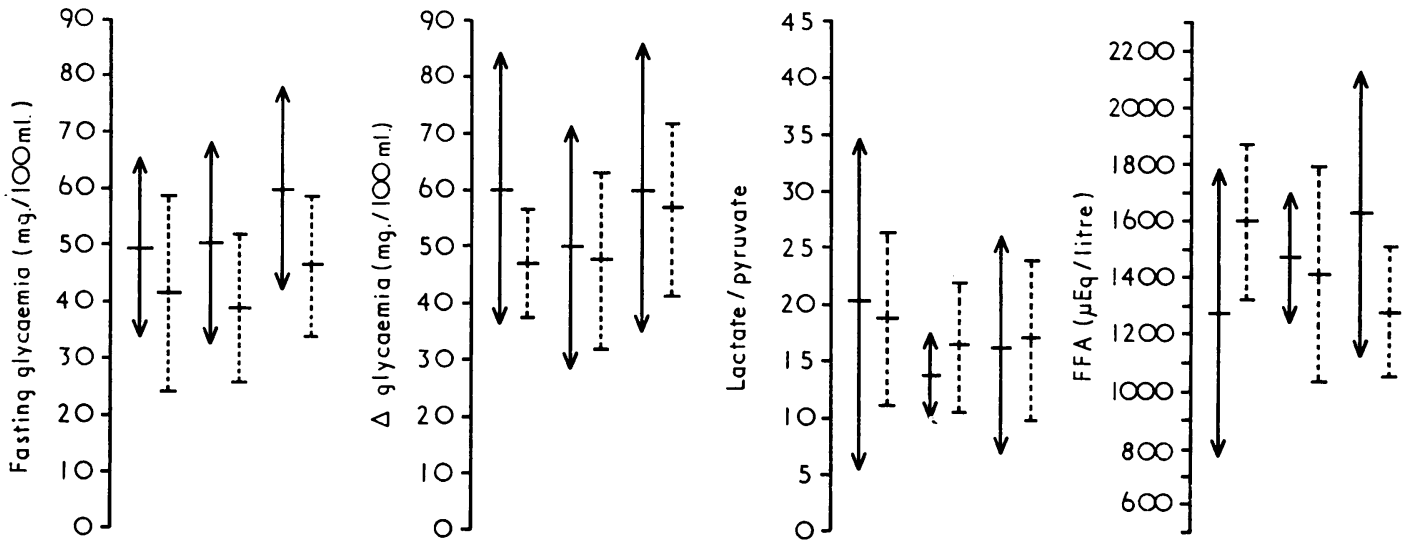

FIG. 3.-Mean values and confidence limits of the mean for fasting glycaemia, glycaemic increase after glucagon, lactate/pyruvate ratio, and FFA level. The mean is represented by the central horizontal line and the confidence limit of the mean $(S E \times t$ of student $)$ by the vertical line $(p=0.01)$. Solid line: controls; dotted line: term infants (small-for-dates). The three pairs of lines in each category refer to days 1, 3, and 5 of life. 
TABLE II

Normal Newborns: Biological Data

\begin{tabular}{|c|c|c|c|c|c|c|c|c|c|c|c|c|}
\hline \multirow{2}{*}{ Case No. } & \multicolumn{3}{|c|}{ Glycaemia (mg./100 ml.) } & \multicolumn{3}{|c|}{$\Delta$ Glycaemia ${ }^{\star}(\mathrm{mg} . / 100 \mathrm{ml})}$. & \multicolumn{3}{|c|}{ Lactate/Pyruvate Ratio } & \multicolumn{3}{|c|}{ Free Fatty Acids ( $\mu \mathrm{Eq} / 1)}$. \\
\hline & $0-24 \mathrm{hr}$. & $24-72 \mathrm{hr}$ & $72-120 \mathrm{hr}$ & $0-24 \mathrm{hr}$. & $24-72 \mathrm{hr}$ & $72-120 \mathrm{hr}$ & $0-24 \mathrm{hr}$ & $24-72 \mathrm{hr}$. & $72-120 \mathrm{hr}$. & $0-24 \mathrm{hr}$. & $24-72 \mathrm{hr}$ & $72-120 \mathrm{hr}$ \\
\hline 1 & - & - & $70 \cdot 0$ & - & - & $36 \cdot 6$ & 一 & - & - & - & - & 1230 \\
\hline 2 & $53 \cdot 1$ & 一 & - & $81 \cdot 0$ & - & - & - & - & - & 1880 & 一 & - \\
\hline 3 & - & 一 & $45 \cdot 5$ & - & 一 & $60 \cdot 0$ & - & - & $16 \cdot 87$ & - & - & 1280 \\
\hline 4 & - & - & - & - & - & - & $13 \cdot 89$ & - & - & - & - & - \\
\hline 5 & $34 \cdot 5$ & - & - & $65 \cdot 0$ & - & - & - & - & - & 1300 & - & - \\
\hline 6 & $38 \cdot 7$ & - & - & $68 \cdot 0$ & - & - & $15 \cdot 16$ & - & - & 1630 & - & - \\
\hline 7 & - & - & $37 \cdot 9$ & - & - & $60 \cdot 0$ & - & - & - & - & - & 1770 \\
\hline 8 & - & - & $36 \cdot 3$ & - & - & $54 \cdot 0$ & - & 一 & - & - & - & 1540 \\
\hline 9 & $60 \cdot 0$ & - & - & $25 \cdot 0$ & - & - & $14 \cdot 45$ & - & - & 1020 & - & - \\
\hline 10 & - & $38 \cdot 6$ & - & - & $77 \cdot 0$ & - & - & $12 \cdot 14$ & - & - & 1320 & - \\
\hline 11 & - & $40 \cdot 1$ & - & - & $46 \cdot 3$ & - & - & $16 \cdot 93$ & $11 \cdot 21$ & 1150 & 1280 & - \\
\hline 12 & $63 \cdot 3$ & - & - & $46 \cdot 2$ & - & - & $14 \cdot 38$ & - & - & - & - & - \\
\hline 13 & - & $37 \cdot 4$ & - & - & $50 \cdot 0$ & - & - & - & - & - & 1500 & - \\
\hline 14 & - & - & - & - & - & - & $25 \cdot 54$ & - & - & 1800 & - & - \\
\hline 15 & - & - & $93 \cdot 3$ & - & - & $21 \cdot 5$ & - & - & $10 \cdot 49$ & - & - & 2200 \\
\hline 16 & $42 \cdot 0$ & - & - & $58 \cdot 0$ & - & - & $10 \cdot 69$ & - & - & 750 & - & - \\
\hline 17 & - & $61 \cdot 7$ & - & - & $46 \cdot 0$ & - & - & $17 \cdot 88$ & - & - & 1530 & - \\
\hline 18 & - & - & $61 \cdot 0$ & - & - & $74 \cdot 0$ & - & - & $15 \cdot 42$ & - & - & 940 \\
\hline 19 & - & $7 \overline{5} \cdot 9$ & - & - & $23 \cdot 0$ & 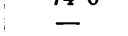 & - & $10 \cdot 61$ & - & - & 1250 & - \\
\hline 20 & - & $55 \cdot 5$ & - & - & $56 \cdot 0$ & - & - & $11 \cdot 20$ & - & - & 1770 & - \\
\hline 21 & - & - & $46 \cdot 2$ & - & - & $41 \cdot 7$ & - & - & $26 \cdot 28$ & - & - & 1530 \\
\hline 22 & $62 \cdot 7$ & - & - & $76 \cdot 0$ & - & - & $22 \cdot 89$ & - & - & 1200 & - & - \\
\hline 23 & - & - & $80 \cdot 0$ & - & - & $130 \cdot 0$ & - & - & $6 \cdot 77$ & - & - & 1130 \\
\hline 24 & - & - & $45 \cdot 1$ & - & - & $74 \cdot 0$ & - & - & $24 \cdot 76$ & - & - & 1730 \\
\hline 25 & - & - & $60 \cdot 0$ & - & - & 73.0 & - & - & 9.51 & - & - & 1980 \\
\hline 26 & - & $41 \cdot 6$ & - & - & $64 \cdot 0$ & - & - & $11 \cdot 62$ & - & - & 1400 & - \\
\hline 27 & - & - & - & - & - & - & - & $15 \cdot 38$ & - & - & 1800 & - \\
\hline 28 & - & - & $57 \cdot 0$ & - & - & $44 \cdot 0$ & - & - & $10 \cdot 15$ & - & - & 2640 \\
\hline 29 & - & - & $85 \cdot 3$ & - & - & $52 \cdot 7$ & - & - & $32 \cdot 00$ & - & - & - \\
\hline 30 & - & $53 \cdot 4$ & - & - & $40 \cdot 0$ & - & - & $15 \cdot 25$ & - & - & 1440 & - \\
\hline 31 & $41 \cdot 8$ & - & - & $63 \cdot 0$ & - & - & $44 \cdot 60$ & - & - & 760 & - & - \\
\hline $\begin{array}{l}\text { Mean } \\
\text { SE }\end{array}$ & $\begin{array}{r}49 \cdot 5 \\
4 \cdot 4\end{array}$ & $\begin{array}{r}50 \cdot 5 \\
5 \cdot 2\end{array}$ & $\begin{array}{r}59 \cdot 8 \\
5 \cdot 7\end{array}$ & $\begin{array}{r}60 \cdot 2 \\
6 \cdot 7\end{array}$ & $\begin{array}{r}50 \cdot 2 \\
6 \cdot 1\end{array}$ & $\begin{array}{r}60 \cdot 0 \\
8 \cdot 2\end{array}$ & $\begin{array}{r}20 \cdot 20 \\
4 \cdot 18\end{array}$ & $\begin{array}{r}13 \cdot 87 \\
1 \cdot 06\end{array}$ & $\begin{array}{r}16 \cdot 04 \\
3 \cdot 00\end{array}$ & $\begin{array}{r}1276 \\
147\end{array}$ & $\begin{array}{r}1476 \\
70\end{array}$ & $\begin{array}{r}1633 \\
158\end{array}$ \\
\hline
\end{tabular}

* Increase in mg./100 ml. of glycaemia after glucagon.

Lubchenco, 1967; Yerushalmy, 1967), in particular as regards neonatal hypoglycaemia (Cornblath et al., 1959; Neligan, Robson, and Watson, 1963). Whatever the criteria of selection used (low birthweight, symptomatic hypoglycaemia, poor nutrition), most authors agree in establishing an intimate relation between hypoglycaemia and low birthweight for maturity.

The mean blood glucose level was not statistically different in 'small-for-dates' babies from those of controls. Individual results nevertheless show a glycaemic level below $30 \mathrm{mg}$. $/ 100 \mathrm{ml}$. in 10 smallfor-dates babies, 5 of whom had levels below 20 $\mathrm{mg} . / 100 \mathrm{ml}$. Of the 13 determinations performed on these 10 children, low levels were observed on 8 occasions within the first 24 hours of life, on 3 occasions between 24 and 72 hours, and on 2 between 72 and 120 hours. 2 subjects had typical clinical manifestations of hypoglycaemia (persistent tremor, jitteriness, cyanosis, limpness, and irritability). Of the 6 newborn infants less than 37 weeks' gestation, 3 had symptomatic hypoglycaemia (blood glucose $<20 \mathrm{mg} . / 100 \mathrm{ml}$.). All 31 controls had blood glucose levels above $30 \mathrm{mg} / 100 \mathrm{ml}$. and were asymptomatic. Our results thus confirm the observations of earlier workers that hypoglycaemia, symptomatic and non-symptomatic, occurs more frequently in 'small-for-dates' babies. Three further points remain to be discussed.

First to be considered is the frequency of hypoglycaemia in our series as compared with that found by other workers. In our investigation of 28 term infants, 5 had glucose levels below 20 $\mathrm{mg} . / 100 \mathrm{ml}$, the incidence of hypoglycaemia thus appearing relatively low. However, if we add 4 'small-for-dates' seen during the period of investigation who, while satisfying our criteria, could not be investigated because of severe hypoglycaemia requiring urgent treatment, the frequency reaches about one-third of cases studied, which is similar to the frequency reported by Neligan et al. (1963) in infants belonging to the 'poor nutrition group'.

The second point concerns the frequent occurr- 
TABLE III

Small-for-dates Newborns: Biological Data

\begin{tabular}{|c|c|c|c|c|c|c|c|c|c|c|c|c|}
\hline \multirow{2}{*}{ Case No. } & \multicolumn{3}{|c|}{ Glycaemia (mg./100 ml.) } & \multicolumn{3}{|c|}{$\Delta$ Glycaemia $^{\star}(\mathrm{mg} . / 100 \mathrm{ml})}$. & \multicolumn{3}{|c|}{ Lactate/Pyruvate Ratio } & \multicolumn{3}{|c|}{ Free Fatty Acids $(\mu \mathrm{Fq} / \mathbf{l})}$. \\
\hline & $0-24 \mathrm{hr}$. & $24-72 \mathrm{hr}$. & $72-120 \mathrm{hr}$. & o-24 hr. & $24-72 \mathrm{hr}$. & $72-120 \mathrm{hr}$. & $0-24 \mathrm{hr}$. & $24-72 \mathrm{hr}$. & $72-120 \mathrm{hr}$. & $0-24 \mathrm{hr}$. & $24-72 \mathrm{hr}$. & $72-120 \mathrm{hr}$. \\
\hline 1 & $16 \cdot 6$ & - & $31 \cdot 1$ & $72 \cdot 0$ & - & $111 \cdot 0$ & - & - & - & 1510 & - & 1500 \\
\hline 2 & $16 \cdot 0$ & - & - & $49 \cdot 0$ & - & - & $15 \cdot 04$ & - & 8.93 & 840 & 1060 & 1390 \\
\hline 3 & - & $53 \cdot 0$ & $65 \cdot 7$ & - & $53 \cdot 0$ & $72 \cdot 3$ & - & - & $9 \cdot 62$ & 2000 & 1640 & 1000 \\
\hline 4 & $43 \cdot 0$ & $53 \cdot 0$ & $56 \cdot 9$ & $55 \cdot 0$ & $24 \cdot 0$ & $37 \cdot 0$ & - & $11 \cdot 48$ & $25 \cdot 75$ & 2100 & 1250 & 1700 \\
\hline 5 & $62 \cdot 0$ & $35 \cdot 8$ & - & $29 \cdot 8$ & $26 \cdot 2$ & - & $10 \cdot 33$ & - & $17 \cdot 48$ & 2400 & - & 1690 \\
\hline 6 & $26 \cdot 6$ & - & - & $54 \cdot 0$ & - & - & - & $10 \cdot 22$ & - & 2000 & - & - \\
\hline 7 & $28 \cdot 9$ & $52 \cdot 0$ & $51 \cdot 0$ & $85 \cdot 0$ & $41 \cdot 0$ & $63 \cdot 0$ & 13.95 & 16.61 & $8 \cdot 41$ & 1730 & 1520 & 1710 \\
\hline 8 & $16 \cdot 0$ & - & - & $30 \cdot 0$ & - & - & $21 \cdot 29$ & - & - & 1440 & - & - \\
\hline 9 & $57 \cdot 0$ & $19 \cdot 0$ & $29 \cdot 0$ & $17 \cdot 0$ & $60 \cdot 0$ & - & $12 \cdot 88$ & $8 \cdot 51$ & 13.98 & 2200 & 1400 & 1300 \\
\hline 10 & $78 \cdot 0$ & $61 \cdot 0$ & $43 \cdot 0$ & $34 \cdot 0$ & - & $52 \cdot 0$ & - & - & 14.06 & 1100 & 700 & 1100 \\
\hline 11 & $51 \cdot 0$ & - & - & $69 \cdot 0$ & - & - & $10 \cdot 62$ & $20 \cdot 86$ & - & 1200 & 2400 & - \\
\hline 12 & $29 \cdot 0$ & 0.0 & 0.0 & $32 \cdot 0$ & $37 \cdot 0$ & $36 \cdot 1$ & - & $14 \cdot 53$ & $11 \cdot 42$ & 1940 & 1920 & 1800 \\
\hline 13 & $29 \cdot 0$ & - & - & $35 \cdot 5$ & - & - & - & - & - & - & - & - \\
\hline 14 & $41 \cdot 8$ & $51 \cdot 0$ & $66 \cdot 0$ & $54 \cdot 0$ & $49 \cdot 0$ & $48 \cdot 0$ & $16 \cdot 00$ & 17.95 & - & 1500 & 1100 & 1020 \\
\hline 15 & $41 \cdot 0$ & - & - & $51 \cdot 0$ & - & - & $14 \cdot 44$ & - & - & - & 700 & - \\
\hline 16 & - & $32 \cdot 0$ & $46 \cdot 0$ & - & $37 \cdot 0$ & $38 \cdot 0$ & 20.55 & $10 \cdot 32$ & - & 1500 & 2000 & 1200 \\
\hline 17 & - & $26 \cdot 2$ & $34 \cdot 8$ & - & $84 \cdot 0$ & $75 \cdot 0$ & - & 16.94 & 33.63 & - & 2120 & $17 j 0$ \\
\hline 18 & $71 \cdot 0$ & $54 \cdot 0$ & $66 \cdot 0$ & $45 \cdot 0$ & $70 \cdot 0$ & 33.0 & $25 \cdot 30$ & $23 \cdot 25$ & - & 1400 & 1360 & 1200 \\
\hline 19 & $26 \cdot 0$ & $34 \cdot 0$ & $41 \cdot 0$ & $47 \cdot 0$ & $47 \cdot 0$ & $62 \cdot 0$ & $52 \cdot 71$ & $31 \cdot 61$ & $27 \cdot 92$ & 1200 & 1030 & 700 \\
\hline 20 & $69 \cdot 6$ & $35 \cdot 8$ & $46 \cdot 4$ & $47 \cdot 0$ & $73 \cdot 0$ & $71 \cdot 0$ & $12 \cdot 02$ & $11 \cdot 76$ & - & 2400 & 1670 & 990 \\
\hline 21 & $47 \cdot 2$ & - & - & $44 \cdot 0$ & - & - & $18 \cdot 62$ & - & - & 1250 & - & - \\
\hline 22 & - & - & - & - & - & - & $20 \cdot 71$ & - & - & 1100 & - & - \\
\hline 23 & $38 \cdot 0$ & $45 \cdot 0$ & $44 \cdot 0$ & $38 \cdot 0$ & $39 \cdot 0$ & $41 \cdot 0$ & $16 \cdot 88$ & $19 \cdot 50$ & $11 \cdot 75$ & - & 1660 & 1100 \\
\hline 24 & $33 \cdot 0$ & - & - & $78 \cdot 0$ & - & - & - & - & - & 2000 & - & - \\
\hline 25 & $37 \cdot 0$ & - & - & $34 \cdot 0$ & - & - & $19 \cdot 26$ & - & - & - & - & - \\
\hline 26 & - & - & $56 \cdot 0$ & - & - & $59 \cdot 0$ & - & - & $22 \cdot 21$ & 980 & - & 1000 \\
\hline 27 & 53.0 & $32 \cdot 8$ & $52 \cdot 0$ & 43.0 & $26 \cdot 4$ & 53.0 & - & - & $14 \cdot 86$ & 1640 & 660 & 1470 \\
\hline 28 & $40 \cdot 0$ & - & $62 \cdot 0$ & $35 \cdot 0$ & - & $54 \cdot 0$ & - & - & - & 1440 & - & 900 \\
\hline $\begin{array}{l}\text { Mean } \\
\text { SE }\end{array}$ & $\begin{array}{r}41 \cdot 3 \\
6 \cdot 1\end{array}$ & $\begin{array}{r}39 \cdot 0 \\
4 \cdot 3\end{array}$ & $\begin{array}{r}46 \cdot 5 \\
4 \cdot 2\end{array}$ & $\begin{array}{r}46 \cdot 9 \\
3 \cdot 3\end{array}$ & $\begin{array}{r}47 \cdot 6 \\
5 \cdot 1\end{array}$ & $\begin{array}{r}56 \cdot 5 \\
5 \cdot 1\end{array}$ & $\begin{array}{r}18 \cdot 81 \\
2 \cdot 57\end{array}$ & $\begin{array}{r}16 \cdot 42 \\
1 \cdot 84\end{array}$ & $\begin{array}{r}16 \cdot 92 \\
2 \cdot 31\end{array}$ & $\begin{array}{r}1603 \\
96\end{array}$ & $\begin{array}{r}1422 \\
128\end{array}$ & $\begin{array}{r}1290 \\
78\end{array}$ \\
\hline
\end{tabular}

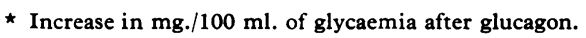

ence of asymptomatic states in our observations. Apparent differences of opinion might partly be attributed to the method of selection used. Most authors study only newborns with symptoms attributable to hypoglycaemia (Cornblath et al., 1964; Tynan and Haas, 1963); others systematically determine blood glucose in low birthweight infants, including true premature and 'small-for-dates' (Baens, Lundeen, and Cornblath, 1963; Pildes et al., 1967). Chance and Bower (1966) approach the problem in the same way as we did; when suspicion arises about 'placental insufficiency', a blood sample for glycaemia is collected. In this way, they were able to detect 20 cases of hypoglycaemia, two-thirds of which were symptomatic, and this proportion is higher than ours.

The third point concerns the time of initiation of the hypoglycaemia, and is still controversial. Tynan and Haas (1963) and Chance and Bower (1966) found, as we did, that more than half of their cases showed symptomatic hypoglycaemia in the first 24 hours. On the other hand, Cornblath and Schwartz (1966b) conclude from their own studies and a review of the literature (Brown and Wallis, 1963; Haworth et al., 1963) that hypoglycaemia becomes evident in the majority of cases after 24 hours of life, only one-quarter of the cases manifesting themselves before that time. In Neligan's work, the samples were obtained after 24 hours in most of the cases (30 out of 33), so that it is not possible to ascertain whether the level was already low during the initial 24 hours (Neligan et al., 1963).

The blood FFA level was found to be very high in both our groups and not significantly different. This observation agrees with the experience of Laron et al. (1967), the high level expressing the intense activity of lipid katabolism in the newborn (Melichar et al., 1965, 1966; Novák et al., 1961, 1965; Persson and Gentz, 1966; Van Duyne and Havel, 1959; Werner, 1967). Like the mean glycaemic levels, the blood FFA fluctuated over a wide range. A close relation between free fatty acids and glucose was therefore impossible to establish.

Irregular variations of lactate/pyruvate ratio 
led us to a similar conclusion. Our average level for lactate/pyruvate ratio was the same in the two groups, and was higher than that reported by Znamenáček and Přibylová (1964).

Glucagon raised the blood glucose level to a similar extent in all our cases. The absence of correlation between fasting glycaemia level and increase of glycaemia after glucagon is illustrated by the fact that in Case 12, even with no glucose in the fasting sample, glycaemia reached a level of $36 \mathrm{mg} . / 100 \mathrm{ml}$. after glucagon.

There are few reports of glucagon tests in 'smallfor-dates' infants. A negative response was obtained in 3 cases described, respectively, by Cornblath et al. (1959), by Neligan (1964), and by Brown and Wallis (1963); a weak response was observed in 4 cases reported, respectively, by Cornblath et al. (1964), by Reisner, Forbes, and Cornblath (1965), by Brown and Wallis (1963), and by Haworth et al. (1963). Reisner et al. (1965) found, however, 4 other cases which responded satisfactorily, as did 1 case reported by Haworth et al. (1963).

The absence of a normal response to glucagon suggested to Cornblath and Schwartz (1966b) an exhaustion of hepatic glycogen stores. It was tempting to combine these findings with observations in hypoglycaemic 'small-for-dates' infants who died in the neonatal period with a reduction of hepatic cells (Naeye, 1967) and of hepatic total carbohydrate (Shelley, 1964). In these cases, however, the exhaustion of liver glycogen may have been related to the mechanism of death. Where infantile hypoglycaemia is unquestionably due to exhausted liver stores of glycogen, glucagon never increases glycaemia (H. Loeb, 1968, unpublished data). It is still surprising to find in our cases that glycogenolysis is available but not called into action, even in the presence of very low levels of circulating glucose.

\section{Summary}

Fasting blood sugar, lactate/pyruvate ratio, blood FFA level, and response to intravenous glucagon $(300 \mu \mathrm{g} . / \mathrm{kg}$.) were determined on the first, third, and fifth day of life in 34 children of low birthweight for gestational age (<expected weight minus $2 \mathrm{SD}$ ), and in 31 normal infants.

There was considerable overlap of the average results of both groups for all these values, and no statistical differences were noted.

Hypoglycaemia was found in 10 of 28 term children of low birthweights and occurred most often during the first 24 hours of life.

Intravenous glucagon induced a satisfactory rise in blood glucose at all fasting blood glucose levels.

It is concluded that depletion of hepatic glycogen stores plays no significant role in the genesis of hypoglycaemia in 'small-for-dates' infants.

\section{REFERENCES}

Baens, S. G., Lundeen, E., and Cornblath, M. (1963). Studies of carbohydrate metabolism in the newborn infant. VI. Levels of glucose in blood in premature infants. Pediatrics, 31, 580 .

Battaglia, F. C., and Lubchenco, L. O. (1967). A practical classification of newborn infants by weight and gestational age. f. Pediat., 71, 159.

Brown, R. J. K., and Wallis, P. G. (1963). Hypoglycaemia in the newborn infant. Lancet, 1, 1278.

Chance, G. W., and Bower, B. D. (1966). Hypoglycaemia and temporary hyperglycaemia in infants of low birth weight for maturity. Arch. Dis. Childh., 41, 279.

Cornblath, M., Odell, G. B., and Levin, E. Y. (1959). Symptomatic neonatal hypoglycemia associated with toxemia of pregnancy. $\mathcal{f}$. Pediat., 55, 545.

- - and Schwartz, R. (1966a). Carbohydrate homeostasis in the neonate (full term and low birth weight). In Disorders of Carbohydrate Metabolism in Infancy, p. 33. Saunders, Philadelphia and London.

- , and - - (1966b). Transient symptomatic hypoglycemia in the neonate. ibid., p. 82.

_, Wybregt, S. H., Baens, G. S., and Klein, R. I. (1964). Symptomatic neonatal hypoglycemia. VIII. Studies of carbohydrate metabolism in the newborn infant. Pediatrics, 33, 388.

Dawkins, M. J. R. (1964). Hypoglycaemia in childhood. Proc. roy. Soc. Med., 57, 1063.

Dole, V. P. (1956). A relation between non-esterified fatty acids in plasma and the metabolism of glucose. $\mathcal{F}$. clin. Invest., 35, 150.

Gloster, J. A., and Harris, P. (1962). Observations on an enzymic method for the estimation of pyruvate in blood. Clin. chim. Acta, 7, 206.

Gruenwald, P. (1965a). Terminology of infants of low birth weight. Develop. Med. Child Neurol., 7, 578.

- (1965b). Some aspects of foetal distress. In Gestational Age, Size and Maturity. (Clinics in Developmental Medicine No. 19), p. 66. Heinemann, London.

- (1966a). Growth of the human fetus. I. Normal growth and its variation. Amer. F. Obstet. Gynec., 94, 1112.

- (1966b). II. Abnormal growth in twins and infants of mothers with diabetes, hypertension, or isoimmunization. ibid., 94, 1120.

Haworth, J. C., Coodin, F. J., Finkel, K. C., and Weidman, M. L. (1963). Hypoglycemia associated with symptoms in the newborn period. Canad. med. Ass. F., 88, 23.

Hendricks, C. H. (1964). Patterns of fetal and placental growth: the second half of normal pregnancy. Obstet. and Gynec., 24, 357.

Laron, Z., Mannheimer, S., Nitzan, M., and Goldmann, J. (1967). Growth hormone, glucose, and free fatty acid levels in mother and infant in normal, diabetic, and toxaemic pregnancies. Arch. Dis. Childh., 42, 24.

Lubchenco, L. O., Hansman, C., and Boyd, E. (1966). Intrauterine growth in length and head circumference as estimated from live births at gestational ages from 26 to 42 weeks. Pediatrics, 37, 403.

Lundholm, L., Mohme-Lundholm, E., and Svedmyr, N. (1963). Comparative investigation of methods for determination of lactic acid in blood and in tissue extracts. Scand. $\mathcal{f}$. clin. Lab. Invest., 15, 311.

Melichar, V., Novák, M., Sabata, V., Hahn, P., and Koldovský, O. (1965). Free fatty acids and glucose in the blood of hypotrophic newborns and newborns from diabetic mothers. The effect of glucose and glucose + insulin infusions to the mother. Physiol. bohemoslov., 14, 553.

$\longrightarrow$ - Zoula, J., Hahn, P., and Koldovský, O. (1966). Energy sources in the newborn. Biol. Neonat. (Basel), 9, 298.

Naeye, R. L. (1967). Infants of prolonged gestation. Arch. Path., 84, 37. 
Neligan, G. A. (1964). Hypoglycaemia in the newborn infant. In Nutricia Symposium. The Adaptation of the Newborn Infant to Extra-uterine Life, p. 42 . Ed. by J. H. P. Jonxis, H. K. A. Visser, and I. A. Troelstra. Stenfert Kroese, Leyden.

- Robson, E., and Watson, J. (1963). Hypoglycaemia in the newborn. A sequel of intrauterine malnutrition. Lancet, $1,1282$.

Novák, M., Melichar, V., Hahn, P., and Koldovský, O. (1961). Levels of lipids in the blood of newborn infants and the effect of glucose administration. Physiol. bohemoslov., 10, 488.

-,-- , and $-(1965)$. Release of free fatty acids from adipose tissue obtained from newborn infants. F. Lipid Res., 6, 91.

Persson, B., and Gentz, J. (1966). The pattern of blood lipids, glycerol and ketone bodies during the neonatal period, infancy and childhood. Acta paediat. scand., 55, 353.

Pildes, R., Forbes, A. E., O'Connor, S. M., and Cornblath, M. (1967). The incidence of neonatal hypoglycemia: a completed survey. F. Pediat., 70, 76.

Reisner, S. H., Forbes, A. E., and Cornblath, M. (1965). The smaller of twins and hypoglycaemia. Lancet, 1, 524.

Shelley, H. J. (1964). Carbohydrate reserves in the newborn infant. Brit. med. F., 1, 273.

-, and Neligan, G. A. (1966). Neonatal hypoglycemia. Brit. med. Bull., 22, 34.

Silverman, W. A., and Sinclair, J. C. (1966). Infants of low birth weight. Neiv Engl. 7. Med., 274, 448.

Tynan, M. J., and Haas, L. (1963). Hypoglycaemia in the newborn. Lancet, 2, 90 .

Van Duyne, C. M., and Havel, R. J. (1959). Plasma unesterified fatty acid concentration in fetal and neonatal life. Proc. Soc. exp. Biol. (N.Y.), 102, 599.

Werner, E. (1967). Die freien Fettsaüren im Plasma während der Perinatalzeit. Forsch. Praxis Fortbild., 18, 537.

Yerushalmy, J. (1967). The classification of newborn infants by birth and gestational age. F. Pediat., 71, 164.

Znamenáček, K., and Přibylová, H. (1964). Some parameters of respiration metabolism in the first 3 days after birth. Acta paediat. (Uppsala), 53, 241.

Correspondence to Dr. H. Loeb, Departments of Paediatrics and Gynaecology, Clinique de Medecine Infantile, Hôpital Universitaire'Saint-Pierre, Rue Haute 320, Bruxelles, Belgium. 